GRASAS Y ACEITES 65 (2)

April-June 2014, e025

ISSN-L: 0017-3495

doi: http://dx.doi.org/10.3989/gya.097313

\title{
Increase in the selenium content of extra virgin olive oil: quantitative and qualitative implications
}

\author{
R. D’Amato, P. Proietti, L. Nasini, D. Del Buono, E. Tedeschini and D. Businelli ${ }^{凶}$ \\ Dipartimento di Scienze Agrarie, Alimentari e Ambientali, Università degli Studi di Perugia, Perugia, Italy \\ Corresponding author: daniela.businelli@unipg.it
}

Submitted: 3 September 2013; Accepted: 13 January 2014

SUMMARY: The biofortification of food crops for human consumption is a direct strategy increasing dietary intake of selenium (Se). The aim of this study was to evaluate the possibility of increasing the Se content of extra virgin olive oil (EVOO) by spraying the olive tree canopy with sodium selenate and the effect of the increase in Se on the chemical properties and sensory characteristics of the EVOO. Se treatments were up to 50 times more effective in enhancing Se content in the EVOO compared with the untreated controls. Se concentration in all the EVOO samples can be considered adequate and useful for providing the human diet with the correct dose of Se. Se-enriched EVOO showed a significant increase in pigment and phenol content. Also, Se treatment does not produce negative effects on fruit characteristics or the sensory quality of EVOO.

KEYWORDS: Biofortification; Chemical parameters; Extra virgin olive oil (EVOO); Fruit characteristics; Nutraceutical value; Selenium ( $\mathrm{Se}$ ); Sensory quality

RESUMEN: Aumento del contenido de selenio en aceites de oliva virgen extra: implicaciones cuantitativas y cualitativas. La biofortificación de cultivos alimenticios para el consumo humano es una estrategia directa para aumentar la ingesta de selenio (Se) en la dieta. El objetivo de este estudio fue evaluar la posibilidad de aumentar el contenido de Se en aceites de oliva virgen extra (AOVE) pulverizando la copa de los olivos con selenato de sodio y el efecto del aumento en el contenido de Se en las propiedades químicas y características sensoriales del AOVE. Los tratamientos con Se fueron muy eficaces consiguiendo aumentar el contenido de Se en el AOVE hasta 50 veces más en comparación con los controles no tratados. La concentración de Se en todas las muestras EVOO puede considerarse adecuada y útil para proporcionar a la dieta humana con la dosis correcta de Se. EVOO-Se enriquecido mostró un aumento significativo en pigmentos y contenido de fenoles. Además, el tratamiento de Se no implica efectos negativos sobre caracteristicas frutales ni sobre la calidad sensorial de AOVE.

PALABRAS CLAVE: Aceite de oliva virgen extra (AOVE); Biofortificación; Calidad sensorial; Características de los frutos; Parámetros químicos; Selenio (Se); Valor nutracéutico

Citation/Cómo citar este artículo: D’Amato R, Proietti P, Nasini L, Del Buono D, Tedeschini E, Businelli D. 2014. Increase in the selenium content of extra virgin olive oil: quantitative and qualitative implications. Grasas Aceites $\mathbf{6 5}$ (2): e025. doi: http://dx.doi.org/10.3989/gya.097313.

Copyright: (C) 2014 CSIC. This is an open-access article distributed under the terms of the Creative Commons Attribution-Non Commercial (by-nc) Spain 3.0 Licence. 


\section{INTRODUCTION}

Selenium (Se) is a very important element for human health, and is involved in defensive mechanisms and the biosynthesis of hormones in adults and babies. Se is mainly involved in the production of the active thyroid hormone, in muscle function, in the reproduction process and in the immune response to some infections (Dhur et al., 1990). Se is also involved in membrane protection and has an anti-cancer action. In addition, Se plays an important role in the antioxidant protection of cells, and as a component of different enzymes such as glutathione peroxidase and thioredoxin reductase (Combs and Grey, 1998, Birringer et al., 2002; Ferrarese et al., 2012).

The essentiality of Se in higher plants is still under debate. Although it is harmful to plants in high concentrations, it exerts beneficial effects at low concentrations. Se increases the tolerance of plants to UV-induced oxidative stress, it delays senescence and promotes the growth of ageing seedlings. Recently, it has been shown that Se is able to regulate the water status of plants under drought conditions (Kuznetsov et al., 2003, Tadina et al., 2007, Germ et al., 2007, Proietti et al., 2013).

The bio-fortification of food crops for human consumption is a direct strategy to increase dietary Se intake; moreover, Se-enriched crops can take advantage of its beneficial effect (Germ et al., 2007, Gissel-Nielsen, 1998).

The content of Se in plants can be increased in different ways: by adding Se to the soil, soaking seeds in an Se solution before sowing, hydroponic and aeroponic cultivation in a nutrient solution containing Se, and the foliar application of Se solutions to plants (Bittman et al., 1997, Pifferi and Poggi, 1998, Salt et al., 2000, Zhao and Shewry, 2011).

Gupta et al. (1988) showed that foliar spraying was preferable in comparison to soil application, and it was due to the more efficient uptake of Se and the absence of residual effects. Furthermore, foliar spraying involves a minimum consumption of $\mathrm{Se}$ salts and is the safest and most economically acceptable way of improving Se content in crops (Djujic et al., 2000). The foliar spraying of Se is effective in increasing the Se content in many crops, such as barley and wheat (Gupta et al., 1988). In green tea, Se foliar spraying increased not only the Se content, but also the plant yield, total amino acids, and the amounts of vitamin C (Hu et al., 2003).

Whereas many papers on the effects of fortifying herbaceous crops with Se are present in the literature, very few studies were aimed at investigating its effects on fruit trees. Nonetheless, it was ascertained that spraying peach and pear with sodium selenate affected the shelf-life of the fruit, delaying the reduction in flesh firmness and fruit ripening (Pezzarossa et al., 2012).
Dugo et al. (2004) studied the correlation between the Se content of Sicilian olive oil and the olive cultivars and areas of provenance; the results obtained provided evidence that both genetic factors (cultivars) and geographic factors (olive-growing zone) may influence the Se content.

Normally, the Se content in olive oil is highly dependent on the amount of Se in the soil and on the ability of plants to take up and accumulate it (Terry et al., 2000).

Mediterranean cuisine is widely considered a healthy and disease-preventive diet. Olives and olive oil, especially extra virgin olive oil (EVOO), are important components of this diet, since they contain a large variety of bioactive compounds (phytochemicals), which are considered to be beneficial for human health (Cicerale et al., 2009). The healthy properties of olive oil are mainly due to the presence of some antioxidant micro-nutrients: phenols and tocopherols.

EVOO contains a considerable amount of phenols that have a great effect on both the stability and the sensory and healthy characteristics of the oil. As water-soluble components, phenols play an important role since they have a wide range of biochemical and pharmaceutical effects, including anticarcinogenic, antiatherogenic, antimicrobial and antioxidant activities (Kohyama et al., 1997; Visioli and Galli, 1998).

Due to their antioxidant activity, the amount of phenols is correlated with the resistance of oil to oxidation and thus to oil stability (Boskov, 1996). Investigations have been carried out to evaluate and compare the antioxidant action of Se and vitamin E. It has been found that the mechanism of the action of $\mathrm{Se}$ as an antioxidant in vivo is different from that of vitamin E. In particular, it was demonstrated that vitamin $\mathrm{E}$ prevents lipid peroxidation more effectively than Se, whereas Se prevents the production of free radicals more effectively than vitamin E (Bettger, 1993; Zhu et al., 1992). Therefore, the simultaneous presence of Se, vitamin $\mathrm{E}$ and phenols in a food, such as EVOO, should substantially increase its antioxidant activity. Many studies have investigated the biological properties of antioxidant and radical-scavenging micro-constituents of olive oil (Tuck and Hayball, 2002), but there is little available data concerning the amount of Se and its effect on oil stability (Bratakos et al., 1987; Simonoff et al., 1988; Dugo et al., 2004).

The aim of this study was to evaluate the possibility of increasing the Se content in EVOO by spraying the olive tree canopy with sodium selenate and the effect of the increase in Se content on the fatty acid composition, phenol and pigment content, oxidation stability and sensory characteristics of the oils. The effect of Se on fruit characteristics was also studied. Well irrigated and water-stressed trees were treated to investigate Se absorption by trees and if the effects of Se on the oil were influenced by soil water availability. 


\section{MATERIALS AND METHODS}

\subsection{Plant material and Se treatments}

The research was carried out in Central Italy (Perugia, about $400 \mathrm{~m}$ a.s.1., $12^{\circ} 23^{\prime} \mathrm{E}$ longitude, $43^{\circ} 5^{\prime} \mathrm{N}$ latitude). Climatic conditions of the experimental site were monitored by a meteorological station. The rainfall pattern in the trial year (2011) was characterized by a scant rainfall in spring, summer and autumn $(187 \mathrm{~mm}, 61 \mathrm{~mm}$ and $139 \mathrm{~mm}$ of rain from March to May, from June to August and from September to November, respectively).

During the experimental period, the highest average of the maximum daily temperatures was in August $\left(33.6^{\circ} \mathrm{C}\right)$, whereas the lowest one was at the beginning of November $\left(15.7^{\circ} \mathrm{C}\right)$.

The experiment used six-year-old potted olive trees of the Maurino cultivar, trained according to the open-center training system and spaced $2.0 \times 1.5 \mathrm{~m}$ between and along the rows (North-South). The trees were about $2.0 \mathrm{~m}$ tall and the canopy had a diameter of approximately $1.0 \mathrm{~m}$ and a height of about $0.9 \mathrm{~m}$. The soil in the pot (approximately $70 \mathrm{~kg}$ ) was medium textured and had a pH of 7.7 and a content of $0.2 \%$ of total nitrogen, 55 and $190 \mathrm{mg} \mathrm{kg}^{-1}$ of assimilable phosphorus and exchangeable potassium, respectively. Each olive was fertilized every year in mid April with the controlled-release fertilizer "Osmocote" ("Scott Italia" 16:8:12 N:P:K) at 100 g per pot. From midMay to mid-September 2011, 27 trees were irrigated (well irrigated trees: WI) to $80 \%$ of the substrate available water (substrate water content approximately $24 \%$ on a dry weight basis), whereas the other 27 trees (water stressed trees: WS) were irrigated to $25 \%$ of the substrate available water (substrate water content approximately $15 \%$ on a dry weight basis). Irrigation was carried out every day in the morning using drip lines (two drippers per pot, each with a flow rate of $\left.4 \mathrm{~L} \mathrm{~h}^{-1}\right)$. The pots were covered with aluminium foil in order to prevent both overheating and the supply of rain water.

At the beginning of July, the trees (both WI and WS) were sprayed with a solution containing two different Se concentrations, i.e. 50 and $150 \mathrm{mg} \mathrm{L}^{-1}$ (respectively $50 \mathrm{Se}$ and $150 \mathrm{Se}$ ), obtained by dissolving the correct amount of sodium selenate in water. ("Sigma-Aldrich" cod. S0882-25g). For each treatment, $0.5 \%$ of the wetting agent "Albamilagro" was added. The controls included in the experiment were sprayed with a solution containing only the wetting agent.

\subsection{Yield per tree and fruit characteristics}

At harvest (beginning of November) the yield per tree, the fruit ripeness indexes (detachment force, flesh firmness and fruit pigmentation) of the fresh fruit and dry weight and oil content were determined.
The yield per tree was determined by weighing the harvested olives for each tree ( 9 trees per treatment).

Detachment force was measured using the "Carpo" hand dynamometer, and flesh firmness was determined by means of an "Effe.gi" dynamometer DT 05 (with $1.0 \mathrm{~mm}$ diameter tip), on about 20 olives per tree. Fruit pigmentation was evaluated using the maturity index (MI) according to the method developed by the Agronomic Station of Jaén (Uceda and Hermoso, 1998) based on the evaluation of the olive skin and pulp colors. MI values range from 0 (100\% intense green skin) to $7(100 \%$ purple flesh and black skin).

The fresh fruit fresh and dry weight (the latter determined by drying three samples of fresh olives per thesis at $90^{\circ} \mathrm{C}$ ) and the oil content (using the "SpectraAlyzer ZEUTEC" - NIR: Near Infra Red on two samples of olives per thesis) were determined.

\subsection{Oil extraction}

The oil samples from approximately $2.5 \mathrm{~kg}$ of olive for each sample (two per thesis) were extracted using a mini olive-mill one day after harvesting (beginning of November), and carried out in the following stages: hammer crushing, 25 minutes rippling at room temperature (about $22{ }^{\circ} \mathrm{C}$ ), centrifugation of the paste to separate the oil with a centrifugation basket without using water, oil filtration with cotton wool and sodium sulphate anhydrous to remove the water and impurities. The oil samples were stored in closed, dark glass bottles in a fridge at $4{ }^{\circ} \mathrm{C}$ until analysis (a week after extraction).

\subsection{Analytical Methods}

The Se content in the oil samples was determined as follows (US EPA Method 3031, 1996). $0.5 \mathrm{~g}$ of oil was mixed with $0.5 \mathrm{~g}$ of finely ground $\mathrm{KMnO}_{4}$, and then $1.0 \mathrm{~mL}$ of concentrated $\mathrm{H}_{2} \mathrm{SO}_{4}$ was added while stirring. A strong, exothermic reaction occurred, and so the sample was ice cooled. The sample was then treated with $2 \mathrm{~mL}$ of concentrated $\mathrm{HNO}_{3} .10 \mathrm{~mL}$ of concentrated $\mathrm{HCl}$ were added to the sample, which was heated until the reaction was complete and then filtered. The filter was washed with hot concentrated $\mathrm{HCl}$ (temperature). The filter paper was transferred to a digestion flask, treated with $5 \mathrm{~mL}$ of concentrated $\mathrm{HCl}$.

Taking into account the low concentration of Se in vegetable oils, we used a highly sensitive, analytical method, which adopted a graphite furnace for use with the atomic absorption spectrophotometer, Shimadzu AA-6800 (GF-AAS; GFA-EX7, Shimadzu Corp., Tokyo, Japan), with a deuterium lamp background correction and a matrix modifier $\left(\mathrm{Pd}\left(\mathrm{NO}_{3}\right)_{2}, 0.5 \mathrm{~mol} \cdot \mathrm{L}^{-1}\right.$ in $\left.\mathrm{HNO}_{3}\right)$. The accuracy of the analytical procedure was obtained by spiking a suitable, known amount of the analyte into a test 
portion of the oil sample, having a known concentration of the added analyte $\left(100 \mu \mathrm{g} \cdot \mathrm{L}^{-1}\right)$, and by analyzing the spiked test portion along with the original sample. The mean percent recovery of Se for 4 samples of spiked olive oil was $92.4 \%$.

The Fatty Acid Methyl Ester (FAME) composition of the oils was determined by GC as FAME. FAME were prepared by saponification/methylation with sodium methylate according to the Commission Regulation (EU) $\mathrm{N}^{\circ} 61 / 2011$. A chromatographic analysis was performed in a Hewlett-Packard 5890 Series II gas chromatograph using a capillary column (SP 2330; Supelco, Bellefonte, PA). The column temperature was kept at $190{ }^{\circ} \mathrm{C}$, and the injector and detector temperatures were $220^{\circ} \mathrm{C}$. The fatty acids (FA) were identified by comparing retention times with standard compounds. The contents of $11 \mathrm{FA}$ were determined and expressed as percentages of FAME (Table 3).

Phenol content was determined as described by Vazquez Roncero et al. (1974) and the results were expressed as $\mu \mathrm{g} \cdot \mathrm{g}^{-1}$ of gallic acid.

Pigments (chlorophyll a and b, and total carotenoids) were determined in $0.5 \mathrm{~g}$ oil samples dissolved in $25 \mathrm{~mL}$ of $95 \%$ diethyl ether. The solution was filtered through a double layer of cheese cloths and absorbances at 662, 646 and $470 \mathrm{~nm}$ were determined using a Genesys 10 BIO spectrophotometer (Wellburn, 1994). The pigments were calculated using the following formulas:

$$
\begin{aligned}
& \mathrm{C}_{\mathrm{a}}\left(\mathrm{mg} \cdot \mathrm{L}^{-1}\right)=(\left(10.05 \times \mathrm{A}_{662}\right)-0.766 \times \mathrm{A}_{644} \\
& \mathrm{C}_{\mathrm{b}}\left(\mathrm{mg} \cdot \mathrm{L}^{-1}\right)=(\left(16.37 \times \mathrm{A}_{644}\right)-3.140 \times \mathrm{A}_{662} \\
& \mathrm{C}_{\mathrm{x}+\mathrm{c}}\left(\mathrm{mg} \cdot \mathrm{L}^{-1}\right)=\left(1000 \times \mathrm{A}_{470}\right)-\left(1.280 \times \mathrm{C}_{\mathrm{a}}\right) \\
& \times \mathrm{C}\left(56.7 \times \mathrm{C}_{\mathrm{b}} / 230\right)
\end{aligned}
$$

Where $C_{a}=$ Chlorophyll $a, C_{b}=$ Chlorophyll $b$, $C_{x+c}=$ Total carotenoids.

The acidity and peroxide number of the oil were determined according to the EEC 2568/91 (1991).

Oxidation induction time (h) was determined using a Rancimat 679 apparatus (Metrohm Co., Herisau, Switzerland) according to Mateos et al. (2006).

A flow of air $\left(20 \mathrm{~mL} \cdot \mathrm{h}^{-1}\right)$ was bubbled through $5.0 \mathrm{~g}$ of oil heated to $110^{\circ} \mathrm{C}, 120$ and $130{ }^{\circ} \mathrm{C}$. The volatile oxidation products were stripped from the oil and dissolved in cold water, thus increasing its conductivity. The time taken to reach an inflection point at the induction curve was measured.

\subsection{Sensory evaluation}

Sensory evaluation of the oil was carried out by nine panel tasters. The tasters were fully trained in the evaluation of virgin olive oil according to the EEC 2568/91 (1991). Panellists completed a profile sheet, giving a score ranging from 0 to 5 for fruity, bitter, pungent and color (the latter was visually determined and values range from $0=$ yellow to $5=$ intense green), and then gave an overall evaluation, assigning scores ranging from 1 to 9 . The results obtained were averaged over all tasters.

\subsection{Statistical Analysis}

The experimental design was a completely randomized 2-factor factorial with 9 trees per treatment, though samples were collected at harvest time from three trees and mixed together for the analyses, so that the final number of true-replicates was three.

All data, with the exception of those of the sensorial evaluation, were submitted to 2-way ANOVA and the means were compared using the Fisher Least Significant Difference at $p=0.05$. A graphical analysis of residuals was used to make sure that the basic assumptions for ANOVA were met and, whenever necessary, data was square-root transformed prior to analyses.

\section{RESULTS AND DISCUSSION}

In general, as expected, yield per tree was higher in WI than in WS (Table 1). Even though they did not completely counteract the effect of drought, Se treatments increased yield per tree. According to Proietti et al. (2013), these results seem to show a positive effect in WS of Se treatments on reducing the negative effects of water stress. In WI trees no differences due to Se treatments were found. The increase in the production of WI compared to WS, and of WS Se-treated trees compared to untreated ones, was due to the increase in fruit fresh weight; no differences in fruit number per node were found (data not shown). Without differences due to Se treatments, the water content percentage of fruit was higher in WI than in WS. However, the differences were not very high (water content about $60 \%$ and 55\% in WI and WS, respectively) and this was probably due to the fact that, in the last period of fruit growth, the fruit water status can recover. The percentage of oil in the fruit, on a dry matter basis, did not significantly differ between WI and WS and Se-treated and untreated trees (data not shown).

The fruits of the WI trees showed a lower pigmentation and higher detachment force and flesh firmness than those of stressed trees. These effects indicate, as expected, that in trees with a higher crop load ripening is slowed down. No differences due to Se treatments were found.

Table 2 reports the Se concentration in EVOO coming from the the trees in the experiment. There was a sharp increase in the Se content due to the treatments. This ranged from 15.0 (WI) to 22.3 (WS) $\mu \mathrm{g} \mathrm{kg}^{-1}$ in oils from Se-untreated 
TABLE 1. Yield per tree and fruit characteristics in olives treated with Se or not, water stressed (WS) or not (WI)

\begin{tabular}{lcccccc}
\hline Sample & $\begin{array}{c}\text { Yield per tree } \\
(\mathbf{g})\end{array}$ & $\begin{array}{c}\text { Fruit fresh weight } \\
(\mathbf{g})\end{array}$ & $\begin{array}{c}\text { Fruit dry weight } \\
(\mathbf{g})\end{array}$ & $\begin{array}{c}\text { Maturity index } \\
(\mathbf{M I})\end{array}$ & $\begin{array}{c}\text { Fruit detachment } \\
\text { force }(\mathbf{N})\end{array}$ & $\begin{array}{c}\text { Flesh firmness } \\
(\mathbf{g})\end{array}$ \\
\hline WI & $610 \pm 16^{\mathrm{d}}$ & $1.91 \pm 0.15^{\mathrm{b}}$ & $0.76 \pm 0.08^{\mathrm{b}}$ & $2.98 \pm 0.45^{\mathrm{a}}$ & $3.39 \pm 0.40^{\mathrm{a}}$ & $386 \pm 16^{\mathrm{d}}$ \\
$\mathbf{W S}$ & $461 \pm 11^{\mathrm{a}}$ & $1.38 \pm 0.17^{\mathrm{a}}$ & $0.61 \pm 0.11^{\mathrm{a}}$ & $4.96 \pm 0.32^{\mathrm{b}}$ & $3.25 \pm 0.42^{\mathrm{a}}$ & $300 \pm 11^{\mathrm{a}}$ \\
$\mathbf{5 0 ~ S e ~ W I ~}$ & $606 \pm 15^{\mathrm{d}}$ & $2.06 \pm 0.15^{\mathrm{bc}}$ & $0.85 \pm 0.08^{\mathrm{bc}}$ & $3.07 \pm 0.25^{\mathrm{a}}$ & $3.52 \pm 0.52^{\mathrm{a}}$ & $380 \pm 18^{\mathrm{d}}$ \\
$\mathbf{5 0 ~ S e ~ W S}$ & $581 \pm 15^{\mathrm{c}}$ & $1.55 \pm 0.16^{\mathrm{a}}$ & $0.68 \pm 0.07^{\mathrm{a}}$ & $4.13 \pm 0.25^{\mathrm{b}}$ & $3.44 \pm 0.48^{\mathrm{a}}$ & $363 \pm 13^{\mathrm{c}}$ \\
$\mathbf{1 5 0} \mathbf{S e} \mathbf{W I}$ & $620 \pm 16^{\mathrm{d}}$ & $2.22 \pm 0.16^{\mathrm{c}}$ & $0.90 \pm 0.05^{\mathrm{c}}$ & $2.25 \pm 0.52^{\mathrm{a}}$ & $3.53 \pm 0.49^{\mathrm{a}}$ & $400 \pm 16^{\mathrm{d}}$ \\
$\mathbf{1 5 0} \mathbf{S e} \mathbf{W}$ & $501 \pm 12^{\mathrm{b}}$ & $1.84 \pm 0.16^{\mathrm{b}}$ & $0.83 \pm 0.16^{\mathrm{b}}$ & $5.04 \pm 0.65^{\mathrm{b}}$ & $3.43 \pm 0.43^{\mathrm{a}}$ & $340 \pm 13^{\mathrm{b}}$ \\
\hline
\end{tabular}

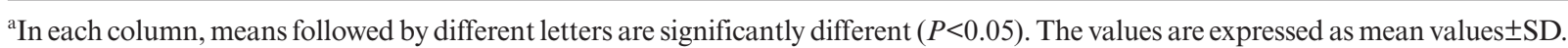

TABLE 2. Se concentration in extra virgin olive oil from treated with Se or not, water stressed

(WS) or not (WI) olives

\begin{tabular}{lc}
\hline Sample & Mean Se content $\left({ }^{\mathrm{a}} \boldsymbol{\mu g ~ \mathbf { ~ k g } ^ { - 1 } )}\right.$ \\
\hline WI & $15.0 \pm 1.5^{\mathrm{a}}$ \\
WS & $22.3 \pm 2.1^{\mathrm{b}}$ \\
$\mathbf{5 0}$ Se WI & $430.8 \pm 7.6^{\mathrm{c}}$ \\
$\mathbf{5 0}$ Se WS & $458.6 \pm 47^{\mathrm{d}}$ \\
150 Se WI & $850.3 \pm 20.2^{\mathrm{e}}$ \\
$\mathbf{1 5 0}$ Se WS & $956.6 \pm 8.5^{\mathrm{f}}$ \\
\hline
\end{tabular}

${ }^{\mathrm{a}}$ Mean and standard deviation are based on three replicate analyses. Anova and multiple comparising testing were performed on square root transformed data.

trees (controls) to values of 430.8 (WI) to 458.6 (WS) $\mu \mathrm{g} \cdot \mathrm{kg}^{-1}$ (50 Se oil samples) and 850.3 (WI) to 956.6 (WS) $\mu \mathrm{g} \cdot \mathrm{kg}^{-1}$ (150 Se oil samples). In the oil samples coming from Se-treated trees, the Se concentration in WS samples was significantly higher than $(\mathrm{P}<0.05)$ in the WI samples, with the exception of the Se dose.

The U.S. Recommended Dietary Allowance(RDA) (National Research Council, 1980) for Se ranges from 75 to $60 \mu \mathrm{g} \cdot \mathrm{day}^{-1}$ for adult men and women, whereas the tolerable dose is set at $400 \mu \mathrm{g} \mathrm{day}^{-1}$. The daily Se requirement in human daily nourishment is not often reached (Pifferi and Poggi, 1998). Considering that a person usually eats about $40 \mathrm{~g}$ per day of EVOO (www.piramideitaliana.it, 2005), the contribution of oil from treated trees to the daily Se RDA could be very important since it is 17.2 (WI) and 18.3 (WS) $\mu \mathrm{g}$ Se (50 Se oil samples), and 34.0 (WI) and 38.6 (WS) $\mu \mathrm{g}$ Se (150 Se oil samples). These Se intakes due to the oils are lower than the RDA and very far from the toxic dose $\left(400 \mu \mathrm{g} \cdot \mathrm{day}^{-1}\right)$. Also taking into account that a person can find Se in other foods, the Se concentration in all the WI and WS oil samples can be considered adequate and useful to provide the human diet with the correct dose of Se. In any case, it is always possible to change the Se concentration of the solution sprayed, if the Se concentration in EVOO is too high.
Acidity, peroxide number, $\mathrm{K}_{232}$ and $\mathrm{K}_{270}$ were not influenced either by the irrigation regime or by the Se treatments, and they were at an optimal level and considerably lower than the limits established by the Commission Regulation (EU) N61/2011 (Table 3). These results agree with those reported by Dettori and Russo (1993) and Patumi et al., (1999) who found that the irrigation regime had no effect on these parameters.

The fatty acid composition was similar in all the oils, with percentages of total saturated fatty acid (SFAs), total polyunsaturated fatty acids (PUFAs) and total monounsaturated fatty acids (MUFAs) ranging from 13.34 to $15.60 \%$, from 9.67 to $10.66 \%$ and 72.65 to $73.94 \%$, respectively. The unsaturated/ saturated acid ratio (ranging from 6.90 to 7.62 ) and the mono-unsaturated/poly-unsaturated acid ratio (ranging from 5.36 to 5.85) were also uninfluenced by irrigation and the Se treatments (Table 3 ).

All the EVOO samples obtained from the WS Se-treated and control trees, showed concentrations of phenols significantly higher $(\mathrm{P}<0.05)$ than those from the WI trees (Table 4). This concurs with several studies, which report an increase in phenol contents in oils as the amount of water availability decreases; in fact, phenols are often associated with abiotic stress defence, signalling disease resistance and are considered a good indicator of the antioxidant capacity of plant tissues (Baidez et al., 2007).

The high phenol content in EVOO could be considered a positive factor, since the higher the phenol content, the greater the antioxidant activity of the oil. Furthermore, they positively influence the oil sensory profile, giving tastes of bitterness and pungency which consumers appreciate at the correct level. In the EVOO samples obtained from the Se-treated trees there was a significant increase of the phenol content compared with the control. The increase in WI was approximately 4 and $24 \%$ for $50 \mathrm{Se}$ and $150 \mathrm{Se}$, respectively, and in WS it was approximately 6 and $10 \%$ for 50 Se and 150 $\mathrm{Se}$, respectively. This means that Se-treatments could cause a further increase in phenol contents in the oils from water stressed trees. As reported by 
TABLE 3. Acidity, peroxide value and fatty acid composition of extra virgin olive oil from treated with Se or not, water stressed (WS) or not (WI) olives

\begin{tabular}{|c|c|c|c|c|c|c|}
\hline & WI & WS & 50 Se WI & $50 \mathrm{Se}$ WS & $150 \mathrm{Se} W I$ & $150 \mathrm{Se} \mathrm{WS}$ \\
\hline $\begin{array}{l}\text { Acidity } \\
\text { (\% oleic acid) }\end{array}$ & $0.23 \pm 0.03^{\mathrm{a}}$ & $0.22 \pm 0.02$ & $0.19 \pm 0.01$ & $0.20 \pm 0.02$ & $0.22 \pm 0.02$ & $0.19 \pm 0.01$ \\
\hline $\begin{array}{l}\text { Peroxide value } \\
\quad\left(\text { meq } \mathrm{O}_{2} \mathrm{~kg}^{-1} \text { of oil }\right)\end{array}$ & $12.1 \pm 0.4$ & $18.3 \pm 0.5$ & $13.6 \pm 0.1$ & $13.2 \pm 0.2$ & $11.4 \pm 0.4$ & $11.1 \pm 0.5$ \\
\hline $\mathrm{K}_{270}$ & $0.12 \pm 0.03$ & $0.13 \pm 0.05$ & $0.12 \pm 0.03$ & $0.11 \pm 0.02$ & $0.16 \pm 0.01$ & $0.14 \pm 0.02$ \\
\hline $\mathrm{K}_{232}$ & $1.89 \pm 0.30$ & $1.90 \pm 0.21$ & $1.78 \pm 0.51$ & $1.95 \pm 0.31$ & $1.54 \pm 0.44$ & $1.95 \pm 0.41$ \\
\hline $\mathrm{C} 16: 0^{\mathrm{b}}$ & $12.99 \pm 0.33$ & $13.35 \pm 0.25$ & $12.89 \pm 0.28$ & $12.91 \pm 0.22$ & $12.57 \pm 0.31$ & $13.31 \pm 0.29$ \\
\hline $\mathrm{C} 16: 1$ & $1.22 \pm 0.01$ & $1.26 \pm 0.01$ & $1.20 \pm 0.02$ & $1.25 \pm 0.03$ & $1.14 \pm 0.02$ & $1.20 \pm 0.01$ \\
\hline C17:0 & $0.03 \pm 0.01$ & $0.03 \pm 0.01$ & $0.03 \pm 0.01$ & $0.03 \pm 0.01$ & $0.03 \pm 0.01$ & $0.04 \pm 0.01$ \\
\hline $\mathrm{C} 17: 1$ & $0.1 \pm 0.05$ & $0.09 \pm 0.05$ & $0.09 \pm 0.02$ & $0.09 \pm 0.02$ & $0.08 \pm 0.01$ & $0.09 \pm 0.02$ \\
\hline C18:0 & $1.37 \pm 0.12$ & $1.84 \pm 0.09$ & $1.48 \pm 0.08$ & $1.65 \pm 0.07$ & $1.49 \pm 0.05$ & $1.69 \pm 0.04$ \\
\hline C18:1 & $71.94 \pm 0.34$ & $71.05 \pm 0.45$ & $71.83 \pm 0.48$ & $72.12 \pm 0.21$ & $72.45 \pm 0.38$ & $71.79 \pm 0.24$ \\
\hline $\mathrm{C} 18: 2$ & $9.91 \pm 0.40$ & $9.7 \pm 0.25$ & $9.65 \pm 0.33$ & $9.05 \pm 0.25$ & $9.34 \pm 0.21$ & $9.1 \pm 0.21$ \\
\hline $\mathrm{C} 18: 3$ & $0.75 \pm 0.03$ & $0.71 \pm 0.02$ & $0.67 \pm 0.02$ & $0.62 \pm 0.03$ & $0.68 \pm 0.02$ & $0.71 \pm 0.03$ \\
\hline C20:0 & $0.25 \pm 0.04$ & $0.28 \pm 0.03$ & $0.24 \pm 0.02$ & $0.26 \pm 0.04$ & $0.25 \pm 0.03$ & $0.27 \pm 0.03$ \\
\hline C20:1 & $0.26 \pm 0.03$ & $0.25 \pm 0.03$ & $0.24 \pm 0.03$ & $0.23 \pm 0.04$ & $0.27 \pm 0.02$ & $0.24 \pm 0.02$ \\
\hline $\mathrm{C} 22: 0$ & $0.07 \pm 0.01$ & $0.1 \pm 0.01$ & $0.06 \pm 0.01$ & $0.07 \pm 0.02$ & $0.07 \pm 0.03$ & $0.08 \pm 0.03$ \\
\hline$\sum$ SFAs & $13.34 \pm 0.51$ & $15.60 \pm 0.39$ & $14.7 \pm 0.55$ & $14.92 \pm 0.37$ & $14.41 \pm 0.43$ & $15.39 \pm 0.40$ \\
\hline$\sum$ PUFAs & $10.66 \pm 0.43$ & $10.41 \pm 0.27$ & $10.32 \pm 0.35$ & $9.67 \pm 0.28$ & $10.02 \pm 0.23$ & $9.81 \pm 0.24$ \\
\hline$\sum$ MUFAs & $73.52 \pm 0.43$ & $72.65 \pm 0.54$ & $73.36 \pm 0.55$ & $73.69 \pm 0.30$ & $73.94 \pm 0.43$ & $73.32 \pm 0.29$ \\
\hline Unsat/Sat & 5.75 & 5.36 & 5.72 & 5.61 & 5.85 & 5.43 \\
\hline MUFAs/PUFAs & 6.90 & 6.98 & 7.11 & 7.62 & 7.38 & 7.47 \\
\hline C18:1/C18:2 & 7.26 & 7.32 & 7.44 & 7.97 & 7.76 & 7.89 \\
\hline
\end{tabular}

${ }^{\mathrm{a}}$ Mean \pm standard deviation $(n=3)$.

${ }^{\mathrm{b}} \mathrm{C} 16: 0$ palmitic, C16:1 palmitoleic, C17:0 margaric, C17:1 margaroleic, C18:0 stearic, C18:1 oleic, C18:2 linoleic, C18:3 linolenic, C20:0 arachidic, C20:1 gadoleic, C22:0 behenic, SFAs saturated fatty acids, PUFAs polyunsaturated fatty acids, MUFAs monounsaturated fatty acids.

TABLE 4. Phenol, chlorophyll and carotenoid contents of extra virgin olive oil from treated with Se or not, water stressed (WS) or not (WI) olives

\begin{tabular}{lcc}
\hline & \multicolumn{1}{c}{ WI } & WS \\
\hline \multicolumn{2}{l}{ Total phenolic compounds $(\text { expressed as } \mu \text { g of gallic acid g })^{\mathrm{a}}$} \\
control & $473 \pm 12^{\mathrm{a}}$ & $626 \pm 15^{\mathrm{c}}$ \\
$\mathbf{5 0 ~ S e}$ & $490 \pm 20^{\mathrm{a}}(3.6)$ & $663 \pm 16^{\mathrm{c}}(5.8)$ \\
$\mathbf{1 5 0} \mathrm{Se}$ & $586 \pm 19^{\mathrm{b}}(23.9)$ & $686 \pm 21^{\mathrm{d}}(9.5)$ \\
Total carotenoids $\left(\mu \mathrm{g} \mathrm{g}^{-1}\right)^{\mathrm{a}}$ & \\
control & $8.08 \pm 0.32^{\mathrm{a}}$ & $10.37 \pm 0.42^{\mathrm{b}}$ \\
$\mathbf{5 0 ~ S e}$ & $12.14 \pm 0.43^{\mathrm{c}}(50.2)$ & $12.68 \pm 0.52^{\mathrm{c}}(22.1)$ \\
$\mathbf{1 5 0} \mathrm{Se}$ & $18.64 \pm 0.41^{\mathrm{e}}(129.6)$ & $16.52 \pm 0.62^{\mathrm{d}}(58.6)$ \\
Total chlorophylls $\left(\mu \mathrm{g} \mathrm{g}^{-1}\right)^{\mathrm{a}}$ & \\
control & $12.70 \pm 0.41^{\mathrm{a}}$ & $14.9 \pm 0.56^{\mathrm{b}}$ \\
$\mathbf{5 0 ~ S e}$ & $20.10 \pm 0.48^{\mathrm{c}}(107.2)$ & $22.60 \pm 0.42^{\mathrm{c}}(51.6)$ \\
$\mathbf{1 5 0} \mathrm{Se}$ & $31.57 \pm 0.56^{\mathrm{e}}(225.4)$ & $27.93 \pm 0.51^{\mathrm{d}}(87.4)$ \\
\hline
\end{tabular}

${ }^{a}$ Means followed by different letters are significantly different $(P<0.05)$. The values are expressed as mean values \pm SD $(n=3)$. Data on brackets are percent of variation from control.
Turlo et al. (2010) the higher levels of phenols in oils from Se-treated trees may be due to a secondary effect, caused by the inhibition of enzymatic phenol oxidation by strong, antioxidant-active $\mathrm{Se}$ compounds. Since no differences in MI due to Se treatments were found (Table 1), it is possible to exclude that the higher levels of phenols in oils from Se-treated trees can be due to a delay in the ripening of the fruit.

In the EVOO samples from Se-untreated trees, the pigment (chlorophylls and carotenoids) concentrations in the oils from WS plants were significantly higher than in the oils from WI trees (Table 4). In the EVOO samples from both WI and WS Se-treated trees, the pigment concentrations were significantly higher than those of the controls $(\mathrm{P}<0.05)$, even though the increase is higher in the samples from the WI trees. The dose of 150 Se induced a significantly higher pigment concentration increase in oils than the 50 Se dose $(\mathrm{P}<0.05)$. With regard to the EVOO samples from trees treated with a $50 \mathrm{Se}$ dose, there was no significant difference in pigment 
TABLE 5. Induction time (h) determined by the Rancimat method at various temperatures in EVOO from treated with Se or not, water stressed (WS) or not (WI) olives

\begin{tabular}{lccc}
\hline Sample & $\begin{array}{c}\text { Induction time } \\
\text { at } \mathbf{1 1 0}{ }^{\circ} \mathbf{C}\end{array}$ & $\begin{array}{c}\text { Induction time } \\
\text { at } \mathbf{1 2 0}{ }^{\circ} \mathbf{C}\end{array}$ & $\begin{array}{c}\text { Induction time } \\
\text { at } \mathbf{1 3 0}{ }^{\circ} \mathbf{C}\end{array}$ \\
\hline WI & $21.1 \pm 1.2$ & $10.6 \pm 1.1$ & $5.0 \pm 0.1$ \\
WS & $30.7 \pm 2.1$ & $13.9 \pm 0.5$ & $6.7 \pm 0.2$ \\
$\mathbf{5 0 ~ S e ~ W I ~}$ & $20.8 \pm 1.3$ & $11.1 \pm 1.2$ & $5.2 \pm 0.2$ \\
$\mathbf{5 0 ~ S e ~ W S ~}$ & $28.2 \pm 1.2$ & $13.5 \pm 1.2$ & $6.4 \pm 0.5$ \\
150 Se WI & $26.1 \pm 1.5$ & $12.9 \pm 1.0$ & $6.1 \pm 0.2$ \\
150 Se WS & $32.0 \pm 2.1$ & $15.2 \pm 0.5$ & $6.6 \pm 0.5$ \\
\hline
\end{tabular}

${ }^{\mathrm{a}}$ Each Rancimat value is listed with precision of one tenth of an hour and is the average of 3 determinations; data are expressed as mean values \pm standard deviation, Mean $\pm \mathrm{SD}(n=3)$.

concentrations between the oils from WI and WS trees. On the contrary, in the EVOO samples from trees treated with a $150 \mathrm{Se}$ dose, the chlorophyll and carotenoid concentrations in the WI oil samples were significantly higher than in the WS samples $(\mathrm{P}<0.05)$

The positive effect of Se in increasing pigment content in oil concurs with what is reported by Chen et al., (2008) who found that in Spirulina platensis, at a concentration of $150 \mathrm{mg} \cdot \mathrm{L}^{-1}$, Se significantly increased $(\mathrm{P}<0.05)$ the level of photosynthetic pigments (including lutein, $\beta$-carotene, and chlorophyll a); by contrast, they found a significant decrease in the content of photosynthetic pigments at higher Se concentrations $\left(\geq 175 \mathrm{mg} \cdot \mathrm{L}^{-1}\right)$. Similar results were obtained by Hawrylak-Nowak (2009) who found a statistically significant increase in the chlorophyll $a$ and $b$ and carotenoid content in $\mathrm{NaCl}$ stressed cucumber plants grown with a $5 \mathrm{mM}$ Se addition. The increased chlorophyll and carotenoid contents in Se-treated trees might be attributed to the efficient scavenging of ROS by antioxidant enzymes (Djanaguiraman et al., 2005).

The color of the EVOO, which depends exclusively on biological compounds such as chlorophylls and carotenoids, is very important, since it is one of the factors that influence consumers' choice; moreover, these pigments play an important role in the oxidative stability due to their antioxidant nature in the dark and pro-oxidant activity in the light (Minguez-Mosquera et al., 1991, Chtourou et al., 2013).

With respect to the EVOO samples from the controls, the induction times in the WS plant oils was higher $\left(30.7 \mathrm{~h}\right.$ at $\left.110^{\circ} \mathrm{C}\right)$ than in those from the WI oils $\left(21.1 \mathrm{~h}\right.$ at $\left.110{ }^{\circ} \mathrm{C}\right)$, which could be related to the higher content in phenols of the WS oil (Table 5). In fact, the literature reports that the oxidative stability of olive oil is greatly affected by its phenol content, since the phenols are the main agents responsible for resistance to oxidation and photo-oxidation (Patumi et al., 2002, Bendini et al., 2007). The treatment of WI and WS trees with the 150 Se dose caused an increase in the induction time of $23.0 \%$ and $4.2 \%$, respectively, with respect to the values of the controls. Consequently, the treatment was useful in producing an increase in the oxidative stability in oils from WI trees, whereas in oil samples from WS trees the effect was not statistically significant. WI and WS trees, treated with a 50 Se dose, did not show any effect which increased the induction time values.

The sensory oil characteristics did not substantially differ between WI and WS and Se treated and untreated trees; the only exception was the bitter and pungent sensations that tend to be higher in WS compared with WI and in Se treated, especially at $150 \mathrm{Se}$, compared to untreated trees (Table 6). The slight increase in the sensations of bitterness and pungency is attributable to the increase in the phenol content. All oil samples were well-balanced with medium-high fruity values. The overall effects on the sensory characteristics of the oil due to treatment indicated that Se did not cause any negative effects on the sensory quality of the oil.

In conclusion, the technique of fortifying olive tree canopies with sodium selenate, in addition to not adversely affecting the fruit characteristics, is a good way to increase the content of Se in EVOO, adding a beneficial element to this important food in the Mediterranean diet which affects human health. Another advantage is the fact that increased $\mathrm{Se}$ in EVOO positively changes some oil properties, such as color intensity, stability and sensory quality.

TABLE 6. Sensory profile of extra virgin olive oils from treated with Se or not, water stressed (WS) or not (WI) olives

\begin{tabular}{lcccccc}
\hline & WI & WS & 50 Se WI & 50 Se WS & 150 Se WI & 150 Se WS \\
\hline Fruity $(\mathbf{0} \div \mathbf{5})$ & 2.5 & 2.5 & 2.0 & 3.0 & 2.5 & 3.0 \\
Bitter $(\mathbf{0} \div \mathbf{5})$ & 2.0 & 3.0 & 2.0 & 3.5 & 3.0 & 3.5 \\
Pungent $(\mathbf{0} \div \mathbf{5})$ & 2.5 & 3.0 & 2.0 & 3.0 & 3.0 & 3.0 \\
Color $(\mathbf{0} \div \mathbf{5})$ & 2.0 & 1.5 & 2.5 & 2.5 & 2.0 & 2.5 \\
Note $(\mathbf{0} \div \mathbf{5})$ & green & green/mature & mature & green & green & green \\
Score $(\mathbf{1} \div \mathbf{9})$ & 8.0 & 8.0 & 7.5 & 8.5 & 8.0 & 8.5 \\
\hline
\end{tabular}




\section{REFERENCES}

Baidez AG, Gomez P, Del Rio JA, Ortuño A. 2007. Dysfunctionality of the xylem in Olea europaea L. plants associated with the infection process by Verticillium dahliae Kleb. Role of phenolic compounds in plant defense mechanism. J. Agric. Food Chem. 55, 3373-3377. http://dx.doi. org/10.1021/jf063166d

Bendini A, Cerretani L, Carrasco-Pancorbo A, GomezCaravaca AM, Segura-Carratero A, Fernandez-Gutierrez A, Lerker G. 2007. Phenolic molecules in virgin olive oils: a survey of their sensory properties, health effects, antioxidant activity and analytical methods. An overview of the last decade. Molecules 12, 1679-1719. http://dx.doi. org/10.3390/12081679

Bettger W. 1993. Zinc and selenium versus general antioxidation. Can. J. Physiol Pharmacol. 49, 721-724.

Birringer M, Pilawa S, Flohč L. 2002. Trends in selenium biochemistry. Nat. Prod. Rep. 19, 693-718.

Bittman S, Buckley WT, Zaychuk K, Brown EAP. 1997. Seed coating for enhancing the level of Se in crops. Patent US 6058649.

Boskov D. 1996. Olive oil chemistry and technology. AOCS Press, Illinois, USA.

Bratakos MS, Zapiropoulos TF, Siskos PA, Ioanou PV. 1987. Selenium in foods produced and consumed in Greece. J. Food Sci.52,817-822. http://dx.doi.org/10.1111/j.1365-2621.1987. tb06735.x.

Combs G, Gray W. 1998. Chemopreventive agents: selenium. Pharmacol. Therapeut. 3, 179-198. http://dx.doi.org/10.1016/ S0163-7258(98)00014-X.

Chen TF, Zheng WJ, Wong YS, Yang F. 2008. Selenium-induced changes in activities of antioxidant enzymes and content of photosynthetic pigments in Spirulina platensis. J. Integrat. Plant Biol. 50, 40-48.

Chtourou M, Gargouri B, Jaber H, Abdelhedi R, Bouaziz M. 2013. Comparative Study of Olive Oil Quality from Chemlali Sfax vs. Arbequina cultivated in Tunisia. Eur. J. Lipid Sci. Tech. 115, 631-640. http://dx.doi.org/10.1002/ ejlt.201200234.

Cicerale S, Conlan XA, Sinclair AJ, Keast RS. 2009. Chemistry and health of olive oil phenolics. Crit. Rev: Food Sci. 49, 218-236. http://dx.doi.org/10.1080/10408390701856223.

Commission Regulation (EU) N61/2011 amending Regulation (EEC) $\mathrm{N}^{\circ} 2568 / 91$ on the characteristics of olive oil and olive-residue oil and on the relevant methods of analysis. OJEU. L 23/1-L 23/14

Dettori S, Russo G. 1993. Influenza della cultivar e del regime idrico su quantità e qualità dell'olio di oliva. Olivae 49 36-43.

Dhur A, Galan P, Hercberg S. 1990. Relationship between selenium, immunity and resistance against infection. Comp. Biochem. Physiol. C. 96, 271-280.

Djanaguiraman M, Devi DD, Shanker AK, Sheeba JA, Bangarusamy U. 2005. Selenium - an antioxidative protectant in soybean during senescence. Plant Soil. 272, 77-86. http://dx.doi.org/10.1007/s11104-004-4039-1.

Djujic IS, Jozanov-Stankov ON, Milovac M, Jankovic V, Djermanovic V. 2000. Bioavailability and possible benefits of wheat intake naturally enriched with selenium and its products. Biol.Trace Elem. Res. 77, 273-285. http://dx.doi. org/10.1385/BTER:77:3:273.

Dugo G, La Pera L, Giuffrida D, Salvo F, Lo Turco V. 2004. Influence of the olive variety and the zone of provenience on selenium content determined by cathodic stripping potentiometry (CSP) in virgin olive oils. Food Chem. 88, 135140. http://dx.doi.org/10.1016/j.foodchem.2003.12.036.

EEC 2568/91. 1991. On the characteristics of olive oil and olive-residue oil and on the relevant methods of analysis. O.J.E.U. $\mathrm{N}^{\circ} \mathrm{L} 248$.

Ferrarese M, Sourestani MM, Quattrini E, Schiavi M, Ferrante A. 2012. Biofortification of spinach plants applying selenium in the nutrient solution of floating system. Vegetable Crops Research Bulletin. 76, 127-136. http://dx.doi.org/10.2478/ v10032-012-0009-y.
Germ M, Stibilj V, Osvald J, Kreft I. 2007. Effects of selenium foliar application on chicory (Cichorium intybus L.). J. Agric. Food Chem. 55, 795-798. http://dx.doi.org/ $10.1021 / \mathrm{jf0629888.}$

Gissel-Nielsen G. 1998. Effects of selenium supplementation of field crops, in Frankenberger Jr. WT, Engberg A .(Eds.), Environmental chemistry of selenium. Marcel Dekker, New York, 99-112.

Gupta UC, Winter KA, McRae KB. 1988. Selenium application of crops through foliar applications. Can. J.l Soil Sci. 68, 519-526. http://dx.doi.org/10.4141/cjss88-050.

Hawrylak-Nowak B. 2009. Beneficial effects of exogenous selenium in cucumber seedlings subjected to salt stress. Biol. Trace Elem. Res. 132, 259-269. http://dx.doi.org/10.1007/ s12011-009-8402-1.

$\mathrm{Hu}$ Q, Xu J, Pang G. 2003. Effect of selenium on the yield and quality of green tea leaves harvested in the early spring. J. Agric. Food Chem. 51, 3379-3381. http://dx.doi. org/10.1021/jf0341417.

Kohyama N, Nagata T, Fujimoto S, Sekiya K. 1997. Inhibition of arachidonate lipoxygenase activities by 2-(3,4-dihydroxyphenyl)ethanol, a phenolic compound from olives. Biosci Biotechnol Biochem. 61, 347-350. http://dx.doi. org/10.1271/bbb.61.347.

Kuznetsov Vas V VV, Kholodova V P VP, Kuznetsov V1. V VV, Yagodin BA. 2003. Selenium regulates the water status of plants exposed to drought. Dokl. Biol. Sci. 390, 266-268. http://dx.doi.org/10.1023/A:1024426104894.

Mateos R, Uceda M, Aguilera MP, Escuderos ME, Beltran Maza G. 2006. Relationship of Rancimat method values at varying temperatures for virgin olive oils. Eur Food Res Technol. 223, 246-252. http://dx.doi.org/10.1007/s00217-005-0185-9.

Minguez-Mosquera MI, Rejano-Navarro L, Gandul-Rojas B, Sanchez Gomez AH, Garrido-Fernandez J. 1991. Colorpigment correlation in virgin olive oil. J. Am. Oil Chem. Soc. 68, 332-336. http://dx.doi.org/10.1007/BF02657688.

National Research Council. 1980. Recommended Dietary Allowances. Ninth Edition, National Academy of Science, Washington, D.C.

Patumi M, D'Andria R, Fontanazza G, Morelli P, Giorio G, Sorrentino G. 1999. Yield and oil quality of intensively trained trees of three cultivars of olive (Olea europaea L.) under different irrigation regimes. J Hortic Sci Biotech. 74, 729-737.

Patumi M, D'Andria R, Marsilio V, Fontanazza G, Morelli G, Lanza B. 2002. Olive and olive oil quality after intensive monocone olive growing (Olea europaea L., cv. Kalamata) in different irrigation regimes. Food Chem. 77, 27-34. http://dx.doi.org/10.1016/S0308-8146(01)00317-X

Pezzarossa B, Remorini D, Gentile ML, Massai R. 2012. Effects of foliar and fruit addition of sodium selenate on selenium accumulation and fruit quality. J Sci. Food Agric. 92, 781786. http://dx.doi.org/10.1002/jsfa.4644.

Pifferi P, Poggi V. 1998. Composition for increasing selenium and decreasing nitrate inside vegetables and use thereof. Patent EP0864257A2.

Proietti P, Nasini L, Del Buono D, D’Amato R, Tedeschini E, Businelli D. 2013. Selenium protects olive (Olea europaea L.) from drought stress. Sci. Hortic. 164, 165-171. http:// dx.doi.org/10.1016/j.scienta.2013.09.034.

Salt D, Ensley BD, Orser C. 2000. Methods for accumulating Se in edible Brassica. Patent US6958435.

Simonoff M, Hamon C, Moretto P, Labador L, Simonoff G. 1988. Selenium in food on France. J. Food Compos. Anal. 1, 295-302. http://dx.doi.org/10.1016/0889-1575(88)90028-2.

Tadina N, Germ M, Kreft I, Breznik B, Gaberščik A. 2007. Effects of water deficit and selenium on common buckwheat (Fagopyrum esculentum Moench.) plants. Photosyntetica. 45(3), 472-476. http://dx.doi.org/10.1007/ s11099-007-0080-7.

Terry N, Zayed AM, De Souza MP, Tarun AS. 2000. Selenium in higher plants. Annu Rev Plant Phys. 51, 401-432. http:// dx.doi.org/10.1146/annurev.arplant.51.1.401.

Tuck KL, Hayball PJ. 2002. Major phenolic compounds in olive oil: metabolism and health effects. J Nutr 
Biochem. 13, 636-644. http://dx.doi.org/10.1016/S09552863(02)00229-2.

Turlo J, Gutowska B, Herold F. 2010. Effect of selenium enrichment on antioxidant activities and chemical composition of Lentinula edodes (Berk.) Pegl. mycelial extracts. Food Chem. Toxicol. 48, 1085-1091. http://dx.doi.org/10.1016/j. fct.2010.01.030

Vázquez Roncero A, Graciani Constante E, Maestro Duran R. 1974. Phenolic compounds in olive fruits. I. Polyphenols in pulp. Grasas Aceites 25, 269-279.

Visioli F, Galli C. 1998. Olive oil phenols and their potential effects on human health. J. Agric. Food Chem. 46, 42924296. http://dx.doi.org/10.1021/jf980049c.

Uceda M, Hermoso M. 1998. La calidad del aceite de oliva, in, Barranco D, Fernandez-Escobar R, Rallo L. (Eds.), El Cultivo del Olivo. Junta de Andalucia Ediciones MundiPrensa, Madrid, Spain, 547-572.

US EPA Method 3031. 1996. Acid digestion of oils for metals analysis by atomic absorption or ICP spectrometry. US
EPA, Office of Solid Wastes and Emergency Response, Washington, DC

Wellburn AR. 1994. The spectral determination of chlorophylls a and $b$, as well as total carotenoids, using various solvents with spectrophotometers of different resolution. J. Plant Physiol. 144, 307-313. http://dx.doi.org/10.1016/ S0176-1617(11)81192-2.

www.piramideitaliana.it 2005. Istituto di Scienza dell'Alimentazione, Università degli Studi "la Sapienza" di Roma.

Zhao FJ, Shewry PR. 2011. Recent developments in modifying crops and agronomic practice to improve human health. Food Policy. 36, S94-S101. http://dx.doi.org/10.1016/j. foodpol.2010.11.011.

Zhu LZ, He YP, Piao JH, Cai QY, Sun CP, Chang JZ, Wu K, Cong JP. 1992. Difference of antioxidative effects between vitamin E and selenium, in, Ong ASH, Packer L. (Eds.), Lipid-soluble antioxidant: biochemistry and clinical applications. Molecular and cell biology updates. Birkhäuser, Basel, CH, 92-104. 